Available online at: http://ejournal-balitbang.kkp.go.id/index.php/iaj

\title{
EFFECTS OF SYNTHETIC ASTAXANTHIN, CHLORELLA, AND SPIRULINA SUPPLEMENTATION IN DIETS ON GROWTH AND PIGMENTATION OF KURUMOI RAINBOWFISH, Melanotaenia parva
}

\author{
Nina Meilisza*\#, Muhammad Agus Suprayudi**), Dedi Jusadi**), \\ Muhammad Zairin Jr.*', and I Made Artika**) \\ *) Research Institute for Ornamental Fish Culture \\ Jl. Perikanan No. 13, Pancoran Mas, Depok 16346 \\ ** Departement of Aquaculture, IPB University \\ Jl. Rasamala, Campus IPB Darmaga Bogor 16680 \\ ${ }^{* *}$ Departement of Biochemistry, IPB University \\ Jl. Rasamala, Campus IPB Darmaga Bogor 16680
}

(Received: December 27, 2019; Final revised: May 11, 2020; Accepted: May 14, 2020)

\begin{abstract}
Several studies have recommended the supplementation of astaxanthin in the Kurumoi rainbowfish diet to enhance its color and growth. However, knowledge regarding the effects of naturally-sourced and synthetically-made carotenoids in fish diets is currently limited. This study's objective was to compare the growth and color performances of M elanotaenia parva by supplementing fish feed with synthetic astaxanthin and natural carotenoids sourced from Chlorella and Spirulina. A total of 12 fish (weight of $1.27 \pm 0.02 \mathrm{~g}$ and total length of $4.70 \pm 0.07 \mathrm{~cm}$ ) were stocked at a density of one fish per liter. Basal feed $(B)$ was used as the control feed. The experimental feeds were: $B$ added with different doses of synthetic astaxanthin (Carophyll ${ }^{\circledR}$ Pink 10\%water-soluble) from low to higher doses as follows: $0.6 \mathrm{~g} \mathrm{~kg}^{-1}$ (AS-L), $2.6 \mathrm{~g} \mathrm{~kg}^{-1}$ (AS-O), and $5.1 \mathrm{~g} \mathrm{~kg}$ ${ }^{1}$ (AS-H); and B added with natural carotenoids of Chlorella sp. (Ch) and Spirulina sp. (Sp) of $8.6 \mathrm{~g} \mathrm{~kg}^{-1}$ and 5.5 $\mathrm{g} \mathrm{kg}^{-1}$, respectively. The experimental diets were given at satiation for 56 days at 8 am and $3 \mathrm{pm}$. The study results showed that the addition of synthetic astaxanthin at a dose of $2.6 \mathrm{~g} \mathrm{~kg}^{-1}$ could increase the fish growth up to $12 \%$ with carotenoid deposition in the fish fin of three times higher than that of the treatments without synthetic astaxanthin. This dose was considered the optimal dose to increase the fish's growth performance and pigmentation compared with the high dose of $5.1 \mathrm{~g} \mathrm{~kg}^{-1}$. Despite having the same nutrient composition, natural carotenoids in Chlorella and Spirulina did not produce better results compared to the low dose of synthetic astaxanthin of $0.6 \mathrm{~g} \mathrm{~kg}^{-1}$.
\end{abstract}

KEYWORDS: $\quad$ synthetic carotenoid; Melanotaenia parva; optimization; growth; color

\section{INTRODUCTION}

Ornamental fish Melanotaenia parva, known as Kurumoi Rainbowfish, is an endemic and vulnerable species of Kurumoi Lake, Papua (Allen, 1996). This fish was successfully cultivated in 2008 by the Research Institute for Ornamental Fish Culture (RIOFC). Kurumoi Rainbowfish has been selected as the ornamental fish candidate for export among the other Rainbowfish domesticated at the RIOFC. However, discoloration and reduced growth were observed on Kurumoi rainbowfish, which had been kept in aquariums. It was suspected that inadequate quality feeds

* Correspondence: Research Institute for Ornamental Fish Culture. Jl. Perikanan No. 13, Pancoran Mas, Depok 16346 Tel. +62 2165162221

E-mail: sirunina@gmail.com were given to the fish and led to the color and growth degradations.

The dietary requirement of ornamental fish is specific and different from that of fish for consumption, particularly for body pigmentation. As ornamental fish cannot synthesize their own pigment de novo (Gouveia et al., 2003), pigment sources have to be supplied through their diet (Sinha \& Asimi, 2007). The pigment responsible for pigmentation is carotenoid, which also plays a vital role in fish growth and survival (Baker et al., 2002). Several studies showed that carotenoid type astaxanthin is effective for pigmentation in red Rainbowfish (Glossolepis incisus), red cherry shrimp (Neocaridina heteropoda), and clownfish (Amphiprion ocellaris) (Subamia et al., 2010; Amin et al., 2012; Yulianti et al., 2014). 
The addition of synthetic astaxanthin of $2.6 \mathrm{~g} \mathrm{~kg}^{-1}$ feed was found to be the best dose to enhance color quality, growth, and health status of Kurumoi Rainbowfish (Melanotaenia parva) (Meilisza et al., 2017; 2018; 2019). However, information regarding the minimum and maximum doses of astaxanthin in the diet of Kurumoi Rainbowfish is not yet available. Previously, selecting synthetic carotenoids to be added in ornamental fish diets is based on purity and ease of application. However, the production cost is high, and access is difficult at certain times to these types of synthetic carotenoids.

In comparison, natural carotenoids are abundantly available. Natural carotenoids suitable for ornamental fish naturally come from microalgae containing at least more than one type of carotenoid. O'Sullivan et al. (2011) mentioned that Chlorella and Spirulina are carotenoid-producing and highly nutritious microalgae.

Chlorella is a single-celled green alga with a dominant carotenoid of lutein, while Spirulina is a bluegreen alga with the primary carotenoid of zeaxanthin. Both algae are widely used in fish feed or as a food supplement (De Chavez \& Bolivar, 2018). Some studies also revealed Chlorella and Spirulina's role in fish color quality (James et al., 2006; Kim \& Lee 2012; Teimouri et al., 2013; Barone et al., 2018; Bakshi et al., 2018).

There are several advantages of synthetic and natural carotenoids for fish species. However, it is not clear which one is more effective to improve the color and growth performances of Melanotaenia parva. Therefore, this study was conducted to compare the effects of different synthetic astaxanthin and natural carotenoid dosages in Chlorella and Spirulina on color quality and growth of Melanotaenia parva.

\section{MATERIALS AND METHODS}

\section{Fish and Rearing}

A total of 12 fries of Kurumoi Rainbowfish $M$ elanotaenia parva per aquarium from natural spawning (average weight of $1.27 \pm 0.02 \mathrm{~g}$ and average length of $4.70 \pm 0.07 \mathrm{~cm}$ ) were placed in an indoor aquarium at a density of one fish per liter. Fish rearing was done in a stagnant water system with a daily water exchange of $1 / 3$ water volume. The fish were kept for 56 days and fed to satiation twice a day at 8 am and $3 \mathrm{pm}$.

\section{Feed and Treatment}

This study used different dosages of synthetic astaxanthin (AS) coded as optimal dose (AS-O), low dose (AS-L), high dose (AS-H), and natural carotenoid coded as Ch for Chlorella and Sp for Spirulina. Basal feed (B) used in this study was a formulated feed in the form of pelleted feed (semi-pure) (see Meilisza et al., 2018). The formulated feed's nutrient composition is listed in Table 1 and determined using proximate analysis (AOAC, 2002). The experimental diets consisted of basal feed added with synthetic astaxanthin (Carophyll ${ }^{\circledast}$ Pink $10 \%$ Cold Water Soluble) of $0.6 \mathrm{~g} \mathrm{~kg}^{-1}$ (AS-L), $2.6 \mathrm{~g} \mathrm{~kg}^{-1}$ (AS-O), $5.1 \mathrm{~g} \mathrm{~kg}^{-1}$ (AS-H), Chlorella sp. $8.6 \mathrm{~g} \mathrm{~kg}^{-1}(\mathrm{Ch})$ and Spirulina sp. $5.5 \mathrm{~g} \mathrm{~kg}^{-1}$ (Sp). The dose of Chlorella and Spirulina was adjusted to the nutrient composition of basal feed (isoprotein, isolipid) based on the study conducted by Ako et al. (2000) (Table 1).

This experiment was designed using the Completely Randomized Design by applying six treatments and three replications. The feed was first produced by dissolving astaxanthin in water, while Chlorella and Spirulina were dissolved in liquid raw material (oil). Later, micronutrients were added, and all ingredients were mixed until the texture was smooth and extruded using a simple pellet machine with a hole diameter of $2 \mathrm{~mm}$. Feed extrudes were air-dried and squeezed or cut to adjust the size of the fish mouth opening. Afterward, the feed was ready to use or stored in a refrigerator to avoid damage.

\section{Sampling and Observation}

Fish rearing in the aquarium was conducted for 56 days by regularly observing the fish growth (weight and length) once every 14 days. After the rearing period was completed (day-56), fish samples were taken and kept in the freezer for subsequent fish tissue tests. The observation of color quality was done on all live fish in each aquarium at the beginning and end of the study. Measurement of color appearance was done using chroma meter CR-400 (Konica Minolta, Osaka, Jepang). Color parameter consisted of $L$ for lightness $(\%$ ranged between 0 for black and 100 for white, C for chroma ( $\%$ ranged of $0-100, \mathrm{H}$ for hue $\left(^{\circ}\right)$ ranged from $0-360, a^{*}$ for red $(+)$ or green $(-), b^{*}$ for yellow (+) and blue (-).

The analysis of total carotenoid in the fish muscle, skin, and fin was conducted after carotenoid extraction of ten fish samples per replication was done, according to the procedure of Schiedt and LiaaenJensen (1995) and measured using Thermo scientific Genesys 10S Uv-Vis spectrophotometer. Parameters observed in this study included survival rate, specific growth rate, feed conversion, analysis of color quantification based on TCF rank, lightness, hue, chroma, red value (a*) and yellow value ( $\left.b^{*}\right)$. Total carotenoid in fish muscle, skin, and fin in the fish samples was also determined. 
Table 1. Composition of experimental diets made of several types and doses of synthetic and natural carotenoids

\begin{tabular}{|c|c|c|c|c|c|c|}
\hline \multirow{2}{*}{$\begin{array}{l}\text { Ingredients } \\
\text { (g/kg) }\end{array}$} & \multicolumn{6}{|c|}{ Fish diets } \\
\hline & B & AS-L & AS-O & AS-H & Ch & Sp \\
\hline Fishmeal & 637 & 636.4 & 634.4 & 632 & 628 & 631.5 \\
\hline Gelatin & 120 & 120 & 120 & 120 & 120 & 120 \\
\hline Dextrin & 110 & 110 & 110 & 110 & 110 & 110 \\
\hline Fish oil & 63 & 63 & 63 & 63 & 63 & 63 \\
\hline Vitamin mix & 20 & 20 & 20 & 20 & 20 & 20 \\
\hline Mineral mix & 30 & 30 & 30 & 30 & 30 & 30 \\
\hline $\mathrm{CMC}^{1}$ & 20 & 20 & 20 & 20 & 20 & 20 \\
\hline Astaxanthin $(10 \%)^{2}$ & 0 & 0.6 & 2.6 & 5.1 & 0 & 0 \\
\hline Chlorella & 0 & 0 & 0 & 0 & 8.6 & 0 \\
\hline Spirulina & 0 & 0 & 0 & 0 & 0 & 5.5 \\
\hline \multicolumn{7}{|c|}{ Nutrient composition (\%dry matter): } \\
\hline Crude protein ${ }^{N S}$ & 51.33 & 51.20 & 50.67 & 50.47 & 50.45 & 50.87 \\
\hline Crude fat ${ }^{\mathrm{NS}}$ & 15.24 & 16.25 & 17.08 & 17.31 & 15.23 & 16.09 \\
\hline Crude fiber NS & 2.82 & 2.99 & 2.46 & 2.97 & 3.34 & 2.98 \\
\hline $\operatorname{Ash}^{\mathrm{NS}}$ & 20.67 & 19.57 & 19.47 & 18.70 & 19.14 & 18.70 \\
\hline $\mathrm{NFE}^{\mathrm{NS}}$ & 9.94 & 9.99 & 10.32 & 10.55 & 11.84 & 11.36 \\
\hline Total carotenoid (mg/kg) & 10.33 & 52.15 & 139.12 & 259.98 & 95.87 & 58.09 \\
\hline
\end{tabular}

\section{Data Analysis}

The collected data on the growth, survival, feed conversion, lightness, chroma, hue, values of $a^{*}$ and $b^{*}$ as well as the total carotenoid in fish tissues were analyzed using one way analysis of variance and followed by Tukey posthoc test to determine significance between treatments using SPSS software version 17.

\section{RESULTS AND DISCUSSION}

\section{Growth, Survival, and Feed Conversion}

Results of the study show that significant differences were evident on the parameters of specific growth rate, relative weight, absolute length, relative length, and feed conversion of fish fed with the experimental diets $(P<0.05)$. The fish given AS$\mathrm{O}$ and AS-H feeds have higher values of specific growth rate, relative weight, and lower feed conversion ratios (Table 2).

The research findings above mean that the synthetic and natural carotenoids and their doses affected the growth and feed conversion despite the fact that no effect was observed on the survival rate (Table 2). This study's result was different from that of Kim \& Lee (2012), where supplementation of various syn- thetic and natural carotenoids in the feed for eight weeks of rearing showed no effect on survival, growth, and feed efficiency of koi fish.

The specific growth rate of Kurumoi Rainbowfish fed with AS-O was significantly higher than that of the fish fed with the other experimental diets, while the fish given AS-L feed was not different from the control. Talebi et al. (2013) reported similar results for rainbow trout. They found that a lower astaxanthin dose $\left(4.1 \mathrm{~g} \mathrm{~kg}^{-1}\right)$ for eight weeks of rearing showed no significant effect on fish growth and survival. In addition, the growth rate of fish fed with AS-L diet was also not different for fish fed with $\mathrm{Ch}$ and $\mathrm{Sp}$. This finding indicates that AS-L feed was not optimal to support a better growth rate of the fish.

Chlorella and Spirulina were not as effective as the optimal dose of synthetic astaxanthin but equaled to AS-L feed. With similar nutrient compositions, carotenoid concentrations in Chlorella and Spirulina were $9.8 \mathrm{~g} \mathrm{~kg}-1$ and $5.8 \mathrm{~g} \mathrm{~kg}-1$, respectively, below the AS-O and AS-H diets' values. Different results were reported by Sun et al. (2012), who added canthaxanthin and Spirulina in koi feed. Their study found that the specific growth rate of fish fed with Spirulina was higher than that of the fish fed with canthaxanthin (synthetic carotenoid) even though total carotenoid 
Table 2. The growth, survival, and feed conversion of Kurumoi Rainbowfish maintained for 56 days

\begin{tabular}{lcccccc}
\hline \multirow{2}{*}{ Parameters } & \multicolumn{7}{c}{ Experimental diets } \\
\cline { 2 - 7 } & B & AS-L & AS-O & AS-H & Ch & Sp \\
\hline Initial weight $(\mathrm{g})$ & $1.24 \pm 0.08$ & $1.29 \pm 0.01$ & $1.29 \pm 0.03$ & $1.26 \pm 0.11$ & $1.27 \pm 0.01$ & $1.27 \pm 0.01$ \\
Final weight $(\mathrm{g})$ & $1.79 \pm 0.08$ & $1.92 \pm 0.03$ & $1.94 \pm 0.08$ & $1.89 \pm 0.18$ & $1.86 \pm 0.02$ & $1.88 \pm 0.03$ \\
Initial length (cm) & $4.66 \pm 0.15$ & $4.61 \pm 0.02$ & $4.66 \pm 0.02$ & $4.72 \pm 0.13$ & $4.76 \pm 0.07$ & $4.79 \pm 0.01$ \\
Final length (cm) & $5.15 \pm 0.17$ & $5.21 \pm 0.04$ & $5.25 \pm 0.02$ & $5.14 \pm 0.13$ & $5.18 \pm 0.03$ & $5.18 \pm 0.08$ \\
Specific growth rate (\%day $\left.{ }^{-1}\right)$ & $0.66 \pm 0.03^{\mathrm{a}}$ & $0.71 \pm 0.02^{\mathrm{ab}}$ & $0.74 \pm 0.04^{\mathrm{b}}$ & $0.73 \pm 0.02^{\mathrm{b}}$ & $0.68 \pm 0.01^{\mathrm{ab}}$ & $0.70 \pm 0.02^{\mathrm{ab}}$ \\
Absolute weight $(\mathrm{g})$ & $0.55 \pm 0.00$ & $0.63 \pm 0.02$ & $0.66 \pm 0.06$ & $0.63 \pm 0.08$ & $0.59 \pm 0.01$ & $0.61 \pm 0.02$ \\
Relative weight $(\%)$ & $44.47 \pm 2.70^{\mathrm{a}}$ & $49.22 \pm 1.41^{\mathrm{ab}}$ & $50.99 \pm 3.23^{\mathrm{b}}$ & $50.17 \pm 1.74^{\mathrm{b}}$ & $46.45 \pm 0.42^{\mathrm{ab}}$ & $48.41 \pm 1.37^{\mathrm{ab}}$ \\
Absolute length (cm) & $0.50 \pm 0.04^{\mathrm{ab}}$ & $0.60 \pm 0.02^{\mathrm{b}}$ & $0.59 \pm 0.02^{\mathrm{b}}$ & $0.42 \pm 0.01^{\mathrm{a}}$ & $0.43 \pm 0.08^{\mathrm{a}}$ & $0.39 \pm 0.09^{\mathrm{a}}$ \\
Relative length (\%) & $10.67 \pm 0.86^{\mathrm{ab}}$ & $13.02 \pm 0.34^{\mathrm{b}}$ & $12.67 \pm 0.46^{\mathrm{b}}$ & $8.98 \pm 0.36^{\mathrm{a}}$ & $8.99 \pm 1.70^{\mathrm{a}}$ & $8.07 \pm 1.79^{\mathrm{a}}$ \\
Survival (\%) & 91.67 & 94.44 & 94.44 & 97.22 & 91.67 & 94.44 \\
Feed conversion (\%) & $2.31 \pm 0.06^{\mathrm{b}}$ & $1.85 \pm 0.28^{\mathrm{ab}}$ & $1.42 \pm 0.27^{\mathrm{a}}$ & $1.48 \pm 0.61^{\mathrm{ab}}$ & $2.21 \pm 0.09^{\mathrm{ab}}$ & $2.00 \pm 0.16^{\mathrm{ab}}$ \\
\hline
\end{tabular}

Note: *) Values followed by different superscript letters within the same row are significantly different $(\mathrm{P}<0.05)$

content in Spirulina was lower than the synthetic canthaxanthin.

The study conducted by Buyukcapar et al. (2007) revealed other findings that the administration of natural carotenoids in rainbow trout at an excessive dose could cause adverse effects on fish growth. These discrepancies are the reasons why the use of natural carotenoids is less popular due to the lack of purity and large quantity required to obtain the desired dose, which will further affect the quality of feed nutrients.

Generally, the values of specific growth rate and feed conversion obtained by Kurumoi Rainbowfish fed with carotenoid-supplemented feed in this study were not so different from the values generated by goldfish of similar size. Gouveia \& Rema (2005) used goldfish of $1.7 \mathrm{~g}$ for four weeks of rearing with the treatment of Chlorella, Spirulina, and synthetic astaxanthin resulted in a specific growth rate of 1.1$1.2 \%$ and feed conversion ratio of $2.0-2.1$.

\section{Color Quality}

At the end of the experiment, the percentages of chroma, hue, and red value of tested fish were significantly different. The fish given AS-O and AS-H feeds had higher values than the fish fed with the natural carotenoids and basal feed $(P<0.05)$. The lightness percentage and yellow value indicated insignificantly different results $(P>0.05)$. Visual observation using TCF revealed that Kurumoi Rainbowfish at the end of the experiment showed different colors according to the feed consumed (Table 3).

Total carotenoid in the muscle of fish fed with the experimental diets and control feed (B) at the end of the study was not significantly different $(P>0.05)$ (Figure 1). In the fish skin, the total carotenoid of fish fed with AS-O was higher and significantly different than the control $(P<0.05)$ (Figure 2), while fish fed with AS-L, AS-H, Ch, and Sp were not significantly different from AS-O and the control. In the fish fin, higher carotenoid values were also found in the fish fed with AS-O and AS-H feed. Furthermore, the administration of AS-L, Ch, Sp, and control feed resulted in a significantly lower total carotenoid $(P<0.05)$ (Figure 3).

Some previous research showed that Chlorella and Spirulina's natural carotenoids were effective in increasing the pigmentation in many fish species. Cells of certain Chlorella strains contain astaxanthin at a significant amount, along with other essential carotenoids (Del Campo et al., 2004). For example, past studies showed that Spirulina powder's administration had increased the pigmentation of rainbow trout Oncorhynchus mykiss (Teimouri et al., 2013; Allaf et al., 2014). Spirulina powder was also able to improve the color quality of fin of red swordtail Xiphophorus helleri and dwarf gourami Trichogaster lalius (James et al., 2006; Bakshi et al., 2018).

Natural carotenoid in Chlorella vulgaris is also effective in replacing the synthetic sources for pigmentation in Cyprinus carpio (Das \& Biswas, 2016) and Carassius auratus (Ezhil et al., 2008). A study conducted by Sun et al. (2012) found that the amount of synthetic carotenoid was comparable to the amount of natural carotenoid in the skin of koi fish fed with canthaxanthin. The values of total synthetic carotenoid of white, black, and red were $2.78,2.20$, and $2.61 \mathrm{mg}$ $\mathrm{kg}^{-1}$, respectively, while those of Spirulina were 3.28, 2.38 , and $3.42 \mathrm{mg} \mathrm{kg}^{-1}$, respectively 


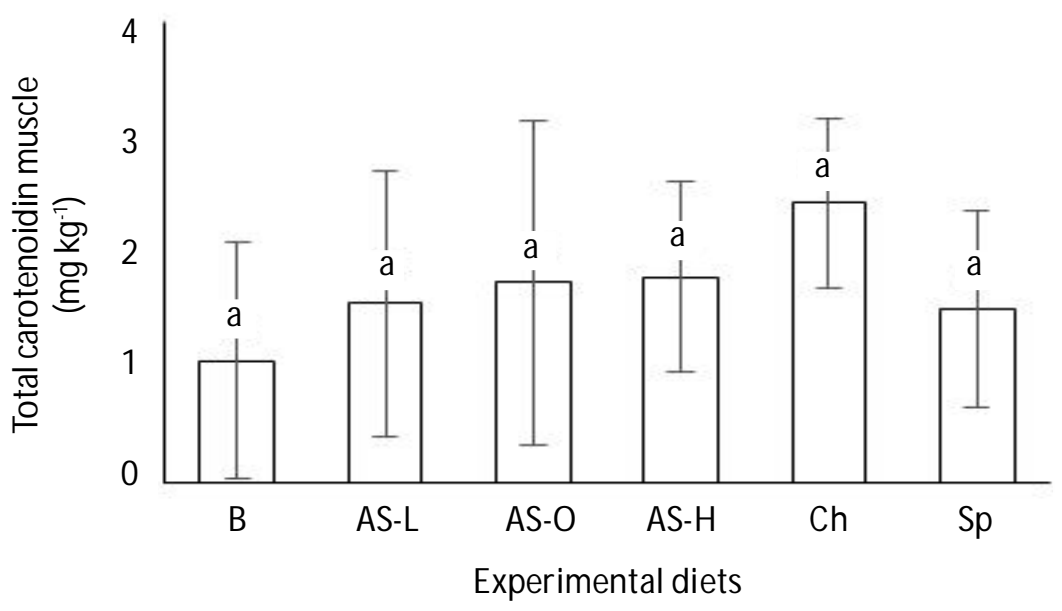

Figure 1. Total carotenoid in the muscle of fish M elanotaenia parva after 56 days of rearing.

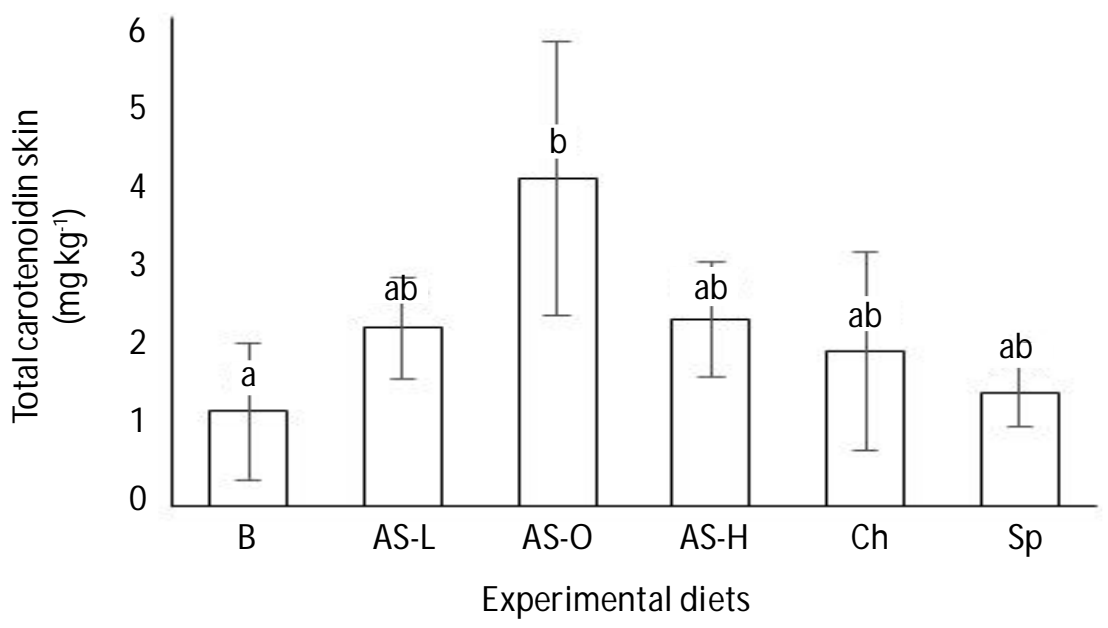

Figure 2. Total carotenoid in the skin of fish M elanotaenia parva after 56 days of rearing.

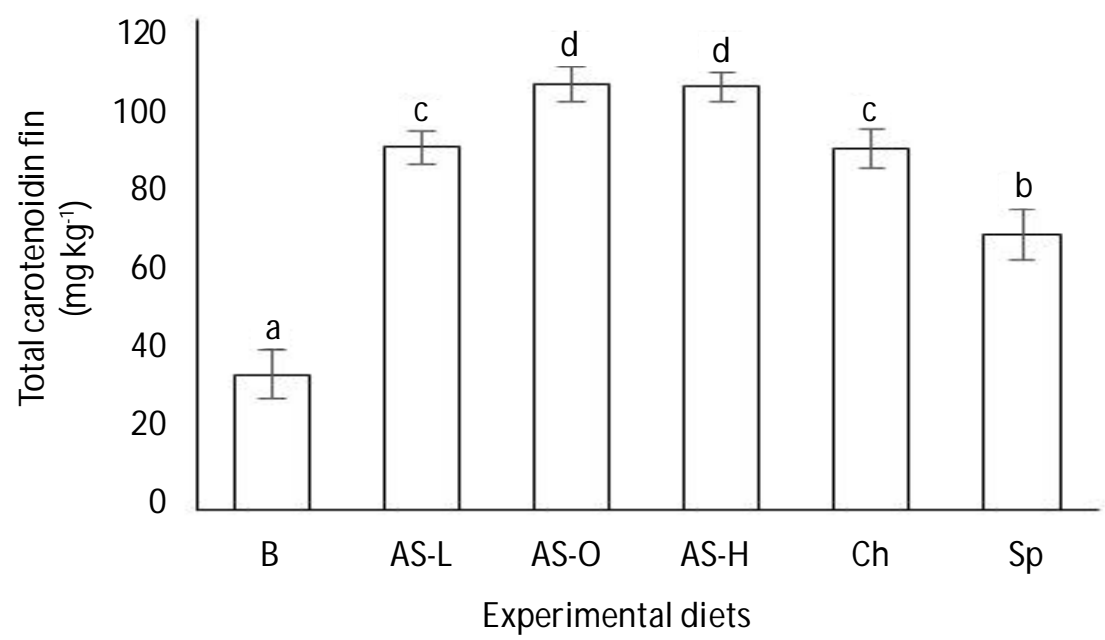

Figure 3. Total carotenoid in the fin of fish Melanotaenia parva after 56 days of rearing. 
Table 3. Color quality of Kurumoi rainbowfish maintained for 56 days

\begin{tabular}{|c|c|c|c|c|c|c|}
\hline \multirow{2}{*}{ Parameters } & \multicolumn{6}{|c|}{ Experimental diets } \\
\hline & B & AS-L & AS-0 & AS-H & Ch & Sp \\
\hline LAw $(\%$ & $55.67 \pm 2.78^{a}$ & $55.90 \pm 3.08^{a}$ & $55.71 \pm 3.64^{a}$ & $53.73 \pm 1.70^{a}$ & $54.88 \pm 3.12^{a}$ & $54.68 \pm 2.38^{\mathrm{a}}$ \\
\hline LAK $(\%)$ & $64.08 \pm 0.79^{\mathrm{a}}$ & $57.50 \pm 3.50^{\mathrm{a}}$ & $61.41 \pm 4.40^{\mathrm{a}}$ & $60.43 \pm 1.23^{\mathrm{a}}$ & $63.89 \pm 3.73^{\mathrm{a}}$ & $65.08 \pm 1.83^{\mathrm{a}}$ \\
\hline CAw $(\%)$ & $3.46 \pm 0.19^{\mathrm{a}}$ & $3.79 \pm 0.45^{a}$ & $3.59 \pm 0.25^{a}$ & $3.75 \pm 0.44^{a}$ & $3.63 \pm 0.52^{a}$ & $3.91 \pm 0.07^{\mathrm{a}}$ \\
\hline CAK $(\%)$ & $3.43 \pm 0.27^{a}$ & $5.43 \pm 0.61^{b}$ & $6.87 \pm 0.23^{c d}$ & $7.95 \pm 0.63^{d}$ & $5.79 \pm 0.14^{b c}$ & $5.02 \pm 0.19^{b}$ \\
\hline HAw (ㅇ) & $301.58 \pm 20.29^{a}$ & $302.44 \pm 24.35^{a}$ & $302.18 \pm 26.53^{a}$ & $291.70 \pm 10.88^{a}$ & $299.63 \pm 16.38^{a}$ & $307.10 \pm 15.38^{\mathrm{a}}$ \\
\hline $\operatorname{HAK}(\underline{)})$ & $282.72 \pm 7.21^{a}$ & $315.53 \pm 20.74^{a b}$ & $323.27 \pm 3.65^{b}$ & $317.93 \pm 15.74^{\mathrm{ab}}$ & $315.38 \pm 15.38^{\mathrm{ab}}$ & $312.82 \pm 8.51^{\mathrm{ab}}$ \\
\hline a* Aw & $1.72 \pm 0.99^{\mathrm{a}}$ & $1.99 \pm 1.56^{\mathrm{a}}$ & $1.76 \pm 1.41^{\mathrm{a}}$ & $1.36 \pm 0.56^{\mathrm{a}}$ & $1.76 \pm 1.01^{\mathrm{a}}$ & $2.27 \pm 0.86^{\mathrm{a}}$ \\
\hline a* Ak & $0.47 \pm 0.39^{a}$ & $3.78 \pm 1.70^{b}$ & $5.50 \pm 0.38^{b}$ & $5.77 \pm 1.59^{b}$ & $3.47 \pm 1.62^{\mathrm{ab}}$ & $3.87 \pm 0.42^{b}$ \\
\hline b* Aw & $-3.04 \pm 0.55^{a}$ & $-2.94 \pm 0.61^{a}$ & $-2.84 \pm 0.85^{a}$ & $-3.47 \pm 0.61^{a}$ & $-3.06 \pm 0.57^{a}$ & $-3.07 \pm 0.57^{a}$ \\
\hline$b * A k$ & $-3.29 \pm 0.34^{\mathrm{a}}$ & $-3.53 \pm 1.20^{\mathrm{a}}$ & $-4.10 \pm 0.32^{a}$ & $-5.25 \pm 1.68^{\mathrm{a}}$ & $-4.31 \pm 1.34^{\mathrm{a}}$ & $-3.16 \pm 0.42^{a}$ \\
\hline TCF Aw of fin & Light yellow & Light yellow & Light yellow & Light yellow & Light yellow & Light yellow \\
\hline TCF Ak of fin & Light yellow & Yellowish-orange & Reddish-orange & Reddish-orange & Bluish-Yellow & Light yellow \\
\hline
\end{tabular}

Note: $\quad$ *Values followed by different superscript letters within the same row are significantly different $(\mathrm{P}<0.05)$

Description: Initial lightness (LAw). Final lightness (LAk). Initial chroma (CAw). Final chroma (CAk). Initial hue (HAw). Final hue (HAk). Initial red value (a*Aw). Final red value (a*Ak). Initial yellow value (b*Aw). Final yellow value (b*Aw). Initial score of Toca Color Finder (TCF Aw). Final score of Toca Color Finder (TCF Ak).

This study also shows that carotenoid deposition in muscle tissue of Kurumoi rainbowfish was really low (1 - $\left.2.5 \mathrm{mg} \mathrm{kg}^{-1}\right)$ and not significantly different, both within the control and experimental diets. However, the values of carotenoid deposition in the fish's skin ranged between 1 - $4 \mathrm{mg} \mathrm{kg}^{-1}$ and were significantly different compared to that of the feed of $2.6 \mathrm{~g}$ $\mathrm{kg}^{-1}$ (AS-0) and the control (Figure 1 and 2). In contrast, several past studies found higher carotenoid depositions in several fish species' muscles despite being administered lower carotenoid doses. The result of a study by Baker et al. (2002) showed that Atlantic salmon Salmo salar fed with astaxanthin feeds $\left(4.5 \mathrm{~g} \mathrm{~kg}^{-1}\right)$ had $2.72 \mathrm{mg} \mathrm{kg}^{-1}$ of astaxanthin and 0.03 $\mathrm{mg} \mathrm{kg}{ }^{-1}$ of canthaxanthin carotenoid in the fish's muscles.

A high carotenoid deposition in Kurumoi Rainbowfish was found to be accumulated in the fish tissues. The highest total carotenoid values were found in the tissues of fish fed with AS-O and AS-H (103-104 mg kg-1), followed by AS-L and Chlorella (88$\left.89 \mathrm{mg} \mathrm{kg}^{-1}\right)$, Spirulina $\left(67 \mathrm{mg} \mathrm{kg}^{-1}\right)$, and the lowest by the control (33 $\mathrm{mg} \mathrm{kg}^{-1}$ ) (Figure 3). These findings suggest that carotenoid's addition has significantly affected the fin pigmentation in Kurumoi Rainbowfish and synthetic carotenoid is more effective than natural carotenoid.

The use of a natural carotenoid in this study sourced from Spirulina powder was ineffective in enhancing the color quality of Kurumoi Rainbowfish. The Chlorella administration also produced a similar result when compared to synthetic carotenoids. Figures 1, 2, and 3 show lower total values of the natural carotenoid deposited in the muscle, skin, fin, and the produced color (Table 3) compared with the lowest administration dose of astaxanthin $0.6 \mathrm{~g} \mathrm{~kg}^{-1}$. It is argued here that Kurumoi Rainbowfish is unable to effectively utilize other types of carotenoid to be converted into the main carotenoid for producing color, namely astaxanthin (Meilisza et al., 2018).

O'Sullivan et al. (2011) argued that carotenoids in Spirulina and Chlorella mainly consisted of zeaxanthin and lutein, respectively. Similarly, this study's findings reconfirm that Spirulina and Chlorella indeed contain different types of carotenoids, which further trigger different pigmentation responses in fish, particularly in visual color appearance (Table 3 ) and total caro tenoid deposited in the fin (Figure 3). The effectiveness of pigmentation of carotenoid feed is not only affected by carotenoid types but also the administered doses. The lowest dose of astaxanthin $(0.6 \mathrm{~g}$ $\left.\mathrm{kg}^{-1}\right)$ produced similar pigmentation effectiveness to that of carotenoid from Chlorella, particularly in the fish fin, but lower than that of the doses of 2.6 and $5.1 \mathrm{~g} \mathrm{~kg}^{-1}$ (Figure 3).

In a study carried out by Teimouri et al. (2013) on rainbow trout, the addition of Spirulina powder of $10.5 \mathrm{~g} \mathrm{~kg}^{-1}$ (2.5\%of fishmeal substitution) showed an insignificant difference in carotenoid concentrations in the fish's muscle compared with the administration of Spirulina powder of $21 \mathrm{~g} \mathrm{~kg}^{-1}$ and astaxanthin of $5.0 \mathrm{~g} \mathrm{~kg}^{-1}$, but significantly different compared with 
a higher dose of Spirulina powder. In Kurumoi Rainbowfish, carotenoid concentrations in the muscles were similar between the control feed and experimental diets. In contrast, the addition of Spirulina of $5.5 \mathrm{~g} \mathrm{~kg}^{-1}$ in feed resulted in a higher carotenoid concentration in Kurumoi Rainbowfish fin compared to the control. A similar finding was mentioned by Bakshi et al. (2018), who found that the addition of Spirulina powder of 2, 4, and $6 \mathrm{~g} \mathrm{~kg}^{-1}$ in the feed significantly increased the concentration of carotenoid in the fin of Trichogaster lalius compared to the control.

A study on rainbow trout conducted by Teimouri et al. (2013) showed that the addition of Spirulina powder $\left(10.5 \mathrm{~g} \mathrm{~kg}^{-1}\right.$ and $\left.21 \mathrm{~g} \mathrm{~kg}^{-1}\right)$ and astaxanthin $(5.0$ $\mathrm{g} \mathrm{kg}^{-1}$ ) did not significantly affect the growth, feed conversion, and hue of the fish. Similarly, the growth, feed conversion, and hue of Kurumoi Rainbowfish given Spirulina powder in this study were not significantly different from that of the fish given AS-L $(5.0 \mathrm{~g}$ $\mathrm{kg}^{-1}$ ) feed. Yet, the measured parameters were different on the application of higher astaxanthin doses of AS-O and AS-H feed. This finding indicated that the addition of Spirulina powder of $5.5 \mathrm{~g} \mathrm{~kg}^{-1}$ in feed was inadequate for Kurumoi Rainbowfish. The carotenoid concentration on the muscle, skin, and fin of Kurumoi Rainbowfish fed with experimental diets showed that the fin deposits a higher concentration of carotenoid, followed by skin and muscle. This result was also shown in the study conducted by James et al. (2006).

A study on guppy fish showed that astaxanthin at a dose of $5.0 \mathrm{~g} \mathrm{~kg}^{-1}$ able to enhance the color quality of the fish's skin (Mirzaee et al., 2012). Coloration intensity in red velvet swordtail (Xiphophorus helleri), Rainbowfish (Pseudomugil furcatus), and topaz cichlid (Cichlasoma myrnae) increased significantly when the fish were given feed containing 1.5-2\% Spirulina platensis rich in carotenoid and $1 \%$ of Haematococcus pluvialis for three weeks (Ako et al., 2000).

In this study, the saturation point of pigmentation was found at a dose of $5.1 \mathrm{~g} \mathrm{~kg}^{-1}$ with total carotenoid value and color quality (lightness, hue, red value, and yellow value) that were not different from the dose of $2.6 \mathrm{~g} \mathrm{~kg}^{-1}$ (Figure 1, 2, 3 and Table 3). Fish appearance resulted from synthetic and natural carotenoid feed might show a color difference, as shown in the study conducted by Yedier et al. (2014). They reported that astaxanthin in feed could enhance orange-red color in red zebra cichlid, while Spirulina could enhance orange and yellow colors. This finding is in line with the result of this study, namely difference in body color is affected by the types of carotenoids consumed by the fish (Table 3 ).
This study also revealed that the red value of Kurumoi Rainbowfish at the end of the experiment (day-56) was significantly different from the control. In contrast, the yellow value was not significantly different in the fish fed with the experimental diets and control. A study conducted by Kim and Lee (2012) on koi fish fed with feed containing different doses of synthetic (astaxanthin and canthaxanthin of 5 and 10 $\mathrm{g} \mathrm{kg}^{-1}$, respectively) and natural (Spirulina of 19 and 34 $\mathrm{g} \mathrm{kg}^{-1}$ ) carotenoids at the same rearing period showed significant changes in the value of red (a*) and yellow (b*) colors. The value of red and yellow colors in the fish fed with feed containing synthetic canthaxanthin was higher than that of the control and fish fed with Spirulina. This finding revealed that higher application of carotenoid doses did not affect pigmentation since Spirulina pigmentation was less effective compared to the synthetic carotenoid. Moreover, Chapman (2000) concluded that the combination of synthetic and natural pigments should be added at the level between $0.04-2 \%$ in feed in order to enhance the coloration of ornamental fish.

Chapman (2000) concluded that astaxanthin was pigmented faster in fish and the retention coefficient of carotenoid decreased with the increasing dose. The author's finding has also been reconfirmed in this study. Moreover, the effectiveness of carotenoid use is also affected by many factors, and the most important factor is fish species that utilize this substance. In Kurumoi Rainbowfish, astaxanthin is the best pigment for pigmentation, growth, and fish health compared to canthaxanthin and lutein which has been discussed in Meilisza et al. (2017) and M eilisza et al. $(2018 ; 2019)$.

\section{CONCLUSION}

Synthetic astaxanthin is more effective for growth and pigmentation in Kurumoi rainbowfish than natural carotenoids. The dose of $2.6 \mathrm{~g} \mathrm{~kg}^{-1}$ of synthetic astaxanthin in the diet is superior on growth and pigmentation of Kurumoi rainbowfish than other testing diets. Future applications of natural carotenoids should consider higher application doses to tap the full benefits of natural carotenoids and be as good synthetic astaxanthin.

\section{ACKNOWLEDGEMENTS}

We gratefully thank the Research Institute for Ornamental Fish Culture for supporting this research. We also thank the nutrition team members at the RIOFC, who provided research support. 


\section{REFERENCES}

Ako, H., Tamaru, C., Asano, S., \& Yamamoto, L. (2000). Achieving natural coloration in fish finder culture. In The $28^{\text {th }}$ Uniunea Nationala a Judecatorilor din Romania (UJNR) aquaculture panel Symposium UNJR Technical Report 28 (pp. 1-4). Kihei, Hawaii, Uniunea Nationala a Judecatorilor din Romania.

Allaf, N.H., Asadi, S.E., \& Abolfazl, B. (2014). Effect of Red Beet Juice (Beta vulgaris) on pigmentation of fillet and growth performance of Rainbow trout (Oncorhynchus mykiss). Biological Forum, 6(2), 110-114.

Allen, G.R. (1996). M elanotaenia parva. The IUCN Red List of Threatened Species 1996:e,T13072A3408864.http://dx.doi.org/10.2305/ IUCN.UK.1996.RLTS. T13072A3408864.en.

Amin, M., Rosidah, \& Lili, W. (2012). Color brightness improvement of male red cherry shrimp (Neocaridina heteropoda) through astaxanthin and canthaxanthin addition in feed. Jurnal Perikanan dan Kelautan, 3(4), 243-252.

Association of Official Analytical Chemists AOAC. (2002). Official M ethods of Analysis. 17th ed. Washington, DC. Association of Official Analytical Chemists.

Baker, R.T.M., Pfeiffer, A.M., Schöner, F.J., \& SmithLemmon. (2002). Pigmentation efficacy of astaxantin and cantaxantin in fresh-water reared Atlantik Salmon, Salmo salar. Animal Feed Science and Technology, 99, 97-106.

Bakshi, S., Behera, S., Saha, S., Mandal, A., Das, A., Bhakta, D., Mondal, A., \& Patra, P. (2018). Influence of Spirulina powder at carotenoids concentration in fin of an ornamental fish Trichogaster Ialius. Journal of Entomology and Zoology Studies, 6(1), 870-873.

Barone, R.S.C., Sonoda, D.Y., Lorenz, E.K., \& Cyrino, J.E.P. (2018). Digestibility and pricing of Chlorella sorokiniana meal for use in tilapia feeds. Scientia Agricola, 75(2), 184-190.

Buyukcapar, H.M., Yanar, M., \& Yanar, Y. (2007). Pigmentation of rainbow trout (Oncorhynchus mykiss) with carotenoids from marigold flower (Tagetes erecta) and red pepper (Capsicum annum). Turkish Journal of Veterinary and Animal Science, 31(1), 712.

Chapman, F.A. (2000). Ornamental Fish Culture, Freshwater. In RR, Stickney, USA (Ed.) Encyclopedia of Aquaculture (p. 602-610). NewYork: John Wiley and Sons.
Das, A.P., \& Biswas, S.P. (2016). Carotenoids and Pigmentation in Ornamental Fish. Journal of Aquaculture and Marine Biology, 4(4), 00093.

De Chavez, P.D.L.C., \& Bolivar, R.B. (2018). Sprulina platensis as an alternative protein source for the African catfish Clarias gariepinus. Aquaculture, Aquarium, Conservation, and Legislation Bioflux, 11(2), 481-494.

Del Campo, J.A., Rodríguez, H., Moreno, J., Vargas, M.Á., Rivas, J., \& Guerrero, M.G. (2004). Accumulation of astaxanthin and lutein in Chlorella zofingiensis Chlorophyta. Applied Microbiology and Biotechnology, 64, 848-854.

Ezhil, J., Jeyanthi, C., \& Narayanan, M. (2008). Marigold as a carotenoid source on pigmentation and growth of red swordtail, Xiphophorus helleri. Turkish Journal of Fisheries and Aquatic Sciences. 9, 99102.

Gouveia, L., Rema, P., Pereira, O., \& Empis, J. (2003). Colouring Ornamental Fish Cyprinus cario and Carassius auratus with micro algal biomass. Aquaculture Nutrition, 9, 123-129.

Gouveia, L., \& Rema, P. (2005). Effect of micro algal biomass concentration and temperature on ornamental goldfish Carassius auratus skin pigmentation. Aquaculture Nutrition, 11, 19-23.

James, R., Sampath, K., Thangarathinam, R., \& Vasudevan, I. (2006). Effect of dietary Spirulina level on growth, fertility, coloration and leucocyte count in red swordtail, Xiphophorus helleri. The Israeli Journal of Aquaculture Bamidgeh, 58(2), 97-104.

Kim, Y.O., \& Lee, S.M. (2012). Effect of dietary inclusion of Spirullina, astaxanthin, canthaxanthin or Paprika on the skin pigmentation of red-and white- colored fancy carp Cyprinus carpio var. Koi. Korean Journal of Fish Aquatechnology Science, 45(1), 43-49.

Meilisza, N., Jusadi, D., Zairin Jr, M., Artika, I.M., Utomo, N.B.P, Kadarini, T., \& Suprayudi, M.A. (2017). Digemstibility, growth and pigmentation of astaxanthin, canthaxanthin or lutein diets in Lake Kurumoi rainbowfish Melanotaenia parva (Allen) cultured species. Aquaculture research, 48(11), 5517-5525.

Meilisza, N., Suprayudi, M.A., Jusadi, D., Zairin Jr, M., Artika, I.M., \& Utomo N.B.P. (2018). Effect of type and dosage of carotenoid in feed on plasma cortisol and glucose of Lake Kurumoi rainbowfish (Melanotaenia parva Allen) due to transportation stress. International Journal of Fisheries and Aquatic Studies, 6(5), 272-277. 
Meilisza, N., Suprayudi, M.A., Jusadi, D., Zairin Jr, M., Artika, I.M., \& Utomo, N.B.P. (2019). Enhancement of color quality, growth, and health status of Lake Kurumoi rainbowfish (M elanotaenia parva) through dietary synthetic carotenoids. Jurnal Akuakultur Indonesia, 18(1), 54-69.

Mirzaee, S., Shabani, A., Rezaee, S., \& Hosseinzadeh, M. (2012). The effect of synthetic and natural pigmentation the color of the guppy fish (Poecilia reticulata). Global Veterinaria, 9(2), 171-174.

O'Sullivan, A.M., O' Callaghan, Y.C., O'Connor, T.P., \& O'Brien, N.M. (2011). The content and bioaccessiblity of carotenoids from selected commercially available health supplements. Proceedings of the Nutrition Society, 70 (OCE3), E62.

Schiedt, K., \& Liaaen-Jensen, K. (1995). Isolation and analysis, In: Britton G, Liaaen-Jensen S, Pfander $\mathrm{H}$, Switzerland (Eds.) Carotenoids, Isolation and Analysis (pp. 1A: 81-108). Basel: Birkhäuser.

Sinha, A., \& Asimi, O.H. (2007). China rose Hibiscus rosasinensis, petals: a potent natural carotenoid source for goldfish Carassius auratus L. Aquaculture Research, 1-6.

Subamia, I.W., Meilisza, N., Mara K.L. (2010). Peningkatan Kualitas Warna Ikan Rainbow Merah (Glossolepis Incisus, Weber 1907) melalui Pengkayaan Sumber Karotenoid Tepung Kepala Udang dalam Pakan. Jurnal Iktiologi Indonesia, 10(1), 1-9.
Sun, X., Chang, Y., Ye, Y., Ma, Z., Liang, Y., Li, T., Jiang, N., Xing, W., \& Luo, L. (2012). The effect of dietary pigments on the coloration of Japanese ornamental carp koi, Cyprinus carpio L. Aquaculture, 342-343, 62-68.

Talebi, M., Khara, H., Zoriehzahra, J., Ghobadi, S., Khodabandelo, A., \& Mirrasooli, E. (2013). Study on effect of red bell pepper on growth, pigmentation and blood factors of rainbow trout (Onchorhynchus mykiss). World Journal of Zoology, 8(1), 17-23.

Teimouri, M., Amirkolaie, A.K., \& Yeganeh, S. (2013). The effects of Spirulina platensis meal as a feed supplement on growth performance and pigmentation of rainbow trout (Oncorhynchus mykiss). Aquaculture, 396-399, 14-19.

Yedier, S., Gumus, E., Livengood, E.J., \& Chapman, F.A. (2014). The relationship between carotenoid type and skin color in the ornamental red zebra cichlid Maylandia estherae. Aquaculture, Aquarium, Conservation and Legislation International Journal of the Bioflux Society, 7(3), 207-216.

Yulianti, E.S., Maharani, H.W., \& Diantari, R. (2014). Efektivitas Pemberian Astaxanthin pada Peningkatan Kecerahan Warna Ikan Badut (Amphiprion ocellaris). e-Jurnal Rekayasa dan Teknologi Budidaya Perairan, 3(1), 313-318. 